\section{New Trends and Issues Proceedings on Humanities and Social Sciences}

'New Trends and Issues Proceedings on Humanities and Social Sciences

\author{
Volume 6, Issue 3 (2019) 08-017 \\ Selected Paper of 8th World Conference on Business, Economics and Management (BEM-2019) 26 - 28 April 2019, \\ Grand Park Lara Hotel Convention Center, Antalya, Turkey
}

www.prosoc.eu

\title{
Life Cycle Assessment as a tool of modern ecological education
}

Adrianna Dybikowska*, University of Zielona Gora, Podgorna 50B 65-246 Zielona Gora, Poland Leszek Kazmierczak-Piwko, University of Zielona Gora, Podgorna 50B 65-246 Zielona Gora, Poland

\section{Suggested Citation:}

Dybikowska, A. \& Kazmierczak-Piwko, L. (2019). Life Cycle Assessment as a tool of modern ecological education. New Trends and Issues Proceedings on Humanities and Social Sciences. [Online]. 6(3), pp 08-017. Available from: www.prosoc.eu

Selection and peer review under responsibility of Prof.Dr. Cetin Bektas, Gaziosmanpasa University, Turkey. ${ }^{\circ} 2019$ United World Center of Research Innovation and Publication. All rights reserved.

\begin{abstract}
The article presents the issues of the Life Cycle Assessment (LCA) use in contemporary ecological education, in relation to the problem of sustainable development. Based on the analysis of the literature, legal norms and strategic documents, the theoretical aspects of LCA as a tool used in numerous areas and environmental management processes were discussed and the significance of its use in the process of shaping ecological awareness of both the whole society and enterprises was demonstrated. The role of using computer programs based on LCA technology (such as SimaPro) in the teaching process at the higher education level was also emphasised.
\end{abstract}

Keywords: Environmental awareness, ecological education, sustainable development, LCA, life cycle assessment.

\footnotetext{
* ADDRESS FOR CORRESPONDENCE: Adrianna Dybikowska, University of Zielona Gora, Podgorna 50B 65-246 Zielona Gora, Poland

E-mail address: a.dybikowska@wez.uz.zgora.pl
} 


\section{1.Introduction}

The requirements of the modern world encourage us to reflect on the state of the environment in which we live. The constantly growing demand for the use of natural resources and the rate of growth of technological progress are not without effect on our planet. The subject of sustainable development is more and more emphasised in the scientific and political discourse, but the methods of its implementation often seem to be ineffective. Therefore, the ecological education system should focus not only on how to inform the population in the most efficient way about the need for sustainable use of the environment and showing the impact of human activities on the security of the natural world, but above all to shape their environmental awareness, so that they can see the dependencies themselves. Thus, the opportunities offered by modern knowledge and technology should be implemented. The use of existing, constantly developing and increasingly advanced tools to support a modern environmental management system allows characterising more effectively the size and scale of the impact of measures taken on the natural environment and shape the surrounding reality in accordance with the principle of intergenerational solidarity. One such tool, playing an increasingly important role in the design of environmental processes, is Life Cycle Assessment (LCA). Therefore, the aim of this article is to show the positive impact of using the LCA tool on shaping the pro-ecological attitudes of both entrepreneurs and entire societies. It presents the possibilities of applying the LCA methodology in the process of modern ecological education.

\section{Sustainable development and ecological education}

The current level of civilisation and developing technology associated with it undoubtedly carry innumerable benefits. Omnipresent progress and access to knowledge, technologies and natural resources make the life of societies more comfortable, safe and convenient. The favours of civilisation, however, carry numerous negative effects, including one fundamental one, namely, the degradation of the natural environment. An indispensable activity allowing for the focus on the quality of people's lives without diminishing the importance of the natural environment has thus become the forecasting of the effects of the development of the modern world (Pawul \& Sobczyk, 2010). The reflection on the need to evaluate the actions taken in the context of natural factors was the emergence of the concept of sustainable development, which was first used in 1972 in Stockholm, at the World UN Conference. As a result of this meeting, the so-called Stockholm Declaration, or Declaration on the Human Environment of 1972 was established, in which 26 important principles of international law on environmental protection were adopted. The concept of sustainability was defined in 1983 by the World Commission on Environment and Development in the Brundtland Report, and the concept was finally developed in 1992 in Rio de Janeiro at the United Nations Conference on Environment and Development (Wozniak, 2011). Sustainable development means the ability to meet the needs of present generations without limiting the ability of future generations to meet their own needs (Pawul \& Sobczyk, 2010) and addresses such issues as: responsibility for environmental protection and improvement, rational resource management, economic development, intergenerational equity, international cooperation, environmental information, ecological standards or environmental impact assessment (Rosicki, 2010).

One of the factors enabling the pursuit of sustainable development is the ability to comprehensively perceive environmental issues and to embed its idea into the consciousness of the society. For this purpose, environmental education is used, which means 'a system of education attitudes and views towards the surrounding world based on respect for the environment' (Terlecka, 20140). As noticed by Niankara et al. (2018) 'Understanding what motivates pro-environmental behaviour (PEB) among the youth is therefore of the utmost interest to policymakers and governments alike, in their quest for a sustainable future and economic development' (Niankara \& Zoungrana, 2018). 
The very subject of this issue has been raised on the international arena for decades (UNESCO and UNEP conference in Tbilisi, 1977, UNESCO International Congress UNEP in Moscow, 1978). The essence of environmental education is also emphasised by Agenda 21 adopted at the Earth Summit in 1992, a program document devoted to the methods of developing and implementing activities for saving the planet and applying sustainable development programmes (Michalska, 2016). The national documents that regulate the scope of environmental education are the Constitution of the Republic of Poland, Acts, including Environmental Protection Law, on nature protection, protection and shaping of the environment, and the National Environmental Policy, the National Strategy of Ecological Education or ordinances and agreements of Ministers. Ecological education was recognised as an important element of civic education and the shaping of multi-faceted awareness became an indispensable tool for ensuring sustainable development (0).

The purpose of ecological education is to stimulate action aimed at improving the environment as a result of perfecting undertakings related to its protection, instilling ecological attitudes aimed at sustainable use of the environment, shaping ecological culture and a sense of responsibility for the environment, learning to comply with ecological norms and bans, shaping cooperation and solidarity in the field of using and protecting the environment and implementing the skills of interdisciplinary reasoning and noticing the dependence between the quality of the environment and the quality of life of societies. These goals are realised through information, awareness, shaping attitudes, participation in solving environmental problems and, above all, developing competencies (Klos, 2014).

In accordance with the core curriculum of pre-school and general education in particular types of schools, nature education starts with elements of ecology (including issues related to waste segregation, water saving or littering) [Regulation of the Minister of National Education...], thus giving a sense of respect to the modelled environment is relatively early. Ecological education, however, is a lifelong process. The knowledge is constantly systematised and enriched (Chrzanowska, 2014), so it is important that the activities undertaken are not focused only on shaping ecological attitudes among children and youth, but that its postulates reach the entire human population.

\section{The essence of LCA}

The LCA is a tool supporting the implementation of pro-environmental attitudes in manufacturing enterprises (Pawul and Sobczyk 2011), as it allows for the collection of data on the analysed product and related production, use and disposal processes. Identification of the amount of materials used, energy and waste entering the environment allows estimating the impact of a product or service on the natural environment and detecting potential environmental threats (Kurzydlo, 2014).

LCA studies can be categorised into two general types: attributional and consequential (Earles \& Halog, 2011). By identifying actual or potential threats, enterprises can make decisions to minimise the negative impact of their operations, thus meeting the requirements of the environmental management system (EMS). According to its requirements (according to ISO 14001:2005), enterprises should use procedures to identify environmental aspects of their operations. Both products and services should be controlled and environmental aspects identified (Buchart-Korol, 2009).

According to ISO 14040:2009 and ISO 14044:2009, this assessment is made by carrying out the following activities (Adamczyk, Dzikuc \& Zarebska, 2015):

1. Definition of the purpose and scope;

2. Analysis of the set of inputs and outputs;

3. Life cycle impact assessment;

4. Interpretation of results. 
The LCA phases are presented in Figure 1.

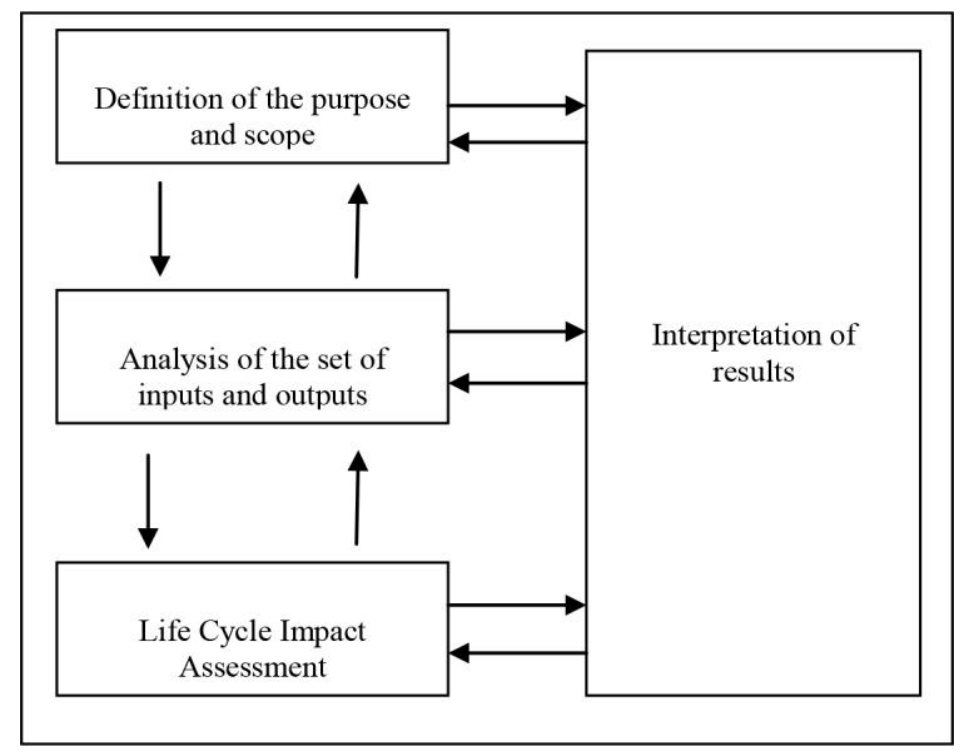

Figure 1. LCA phases

[Source: Kaminska and Skarbek-Zabkin (2015)]

\section{Definition of the purpose and scope}

Stage 1 consists in defining the limit of research, formulation of assumptions and indication of existing limitations. It is also necessary to indicate the system of the studied product, i.e., a set of related (material and energetic) smallest elements-unit processes, its functions and a functional unit (Buchart-Korol, 2009).

\section{Analysis of the set of inputs and outputs $-\mathrm{LCl}$}

The analysis of the set of input and inputs, or Life Cycle Inventory ( $\mathrm{LCl})$, consists in gathering data on all energy and chemical elements collected from and admitted to the environment, as well as using quantitative procedures, i.e., determining inputs and outputs for a particular product system and the unit processes specified in it during its life cycle (Kaminska \& Skarbek-Zabkin, 2015).

\section{Life Cycle Impact Assessment-LCIA}

Life Cycle Impact Assessment (LCIA) is performed to estimate the environmental impact of the analysed product system. The value of the category indicator is calculated by means of the so-called classification, or assignment for each impact category (carcinogenic compounds, organic compounds, inorganic compounds, climate change, radiation, ozone hole, eco-toxicity, eutrophication, land management, minerals, fossil fuels) category indicator, and then the application of characterisation parameters. The collected index values indicate environmental aspects of product inputs and outputs (Kaminska \& Skarbek-Zabkin, 2015).

\section{Interpretation of results}

The last stage includes the results of the collection analysis ( $\mathrm{LCI})$ and the results of the impact assessment (LCIA). The results of these phases are analysed in order to draw conclusions, formulate recommendations and interpret the possibilities of their application in practice (Buchart-Korol, 2009).

The fulfilment of the above activities allows documenting the existing and potential impacts of the product on the environment, taking into account all stages of its life, and analysing the impact of 
remedial measures in relation to the emergence of new environmental problems. Moreover, it becomes possible to set priorities in the improvement of products as well as to compare various solutions to the same problem. Despite numerous difficulties in the application of LCA [timeconsuming and difficult to collect data (Adamczyk, Dzikuc \& Zarebska, 2015)], this method is characterised by high flexibility, which allows for its use both in the macro sphere, by the public sector and in the micro scale, by individual organisations (Joachimiak-Lechaman, 2015). The usefulness of the LCA method is also demonstrated by its potential, a wide range of applications, the possibility of combining economic and ecological aspects, and usefulness in making decisions that condition the fact that LCA is a tool recommended in European Union strategies and documents promoting sustainable development principles (Kowalski, Kulczycka \& Goralczyk, 2007].

\section{The place of LCA in the system of modern ecological education}

Ecological education aims to shape environmental awareness, that is, the rational approach of societies to the environment and knowledge about the connections between man and nature. This term applies to both companies and consumers (Grzybowska-Brzezinska, 2011). Ecological awareness is expressed in all activities of producers and purchasers of products that help reduce the negative impact on the environment. The LCA method fits perfectly into the requirements of the effectiveness of tools used in the planning of these projects because it allows assessing both projects supporting decision-making processes and those focused on environmental effects (Nitkiewicz, 2015), such as:

a) Eco-innovations

Eco-innovations, i.e., all forms of innovative activities related to production processes, new products as well as business and management methods, are aimed at the effectiveness of protection, significant reduction of threats to the environment or reduction of negative effects of raw materials consumption (Graczyk \& Kazmierczak-Piwko, 2011). LCA favours the design and implementation of innovations because it allows identifying key areas of the company's operations on the environment, evaluating changes in the impact of innovation and designing environmental parameters. The tool can refer to the product, the process and the organisation of the company.

\section{b) Eco-designing}

The LCA method can be equally effectively used during eco-design, focusing on looking for design solutions that integrate economic, technological and ecological factors. LCA allows designing environmental parameters of the product, identifies key areas of the company's operations on the environment and optimises the product life cycle, thus being one of the most advanced and popular tools supporting eco-design (Buchart-Korol, 2010).

\section{c) Packaging management}

The assessment of the life cycle of packaging waste is recommended by many EU documents, and such a provision can be found, among the others, in the Directive of the European Parliament and of the Council 2008/98/EC (Lesiuk, Kusmierz \& Oleszczuk, 2012]. The use of LCA allows assessing the impact of packaging management on the environment, estimating the impact of potential solutions, identifying environmental impacts of packaging in all phases of the life cycle, estimating pollution emissions and material flows, and carrying out optimisation.

d) Eco-labelling

LCA is also an auxiliary tool during the eco-labelling process, that is, the application of special quality marks on ecological products, which confirm that the product is 'environmentally friendly' (Poskrobko, 2007). The use of LCA helps to prepare the documentation necessary for environmental 
certification, allows for an assessment of the environmental impact of the product and also promotes the development of environmental declarations (Nitkiewicz, 2015).

e) Ecological investments, EMS and changes in routine practices

With regard to ecological investments, LCA enables to estimate the company's environmental impact as well as to assess environmental aspects in development scenarios. The positive impact of life cycle assessment can also be applied to the design of the EMS. LCA diagnoses areas of the enterprise that affect the environment, allows monitoring effects and carrying out environmental reviews and also identifies the possibility of introducing pro-ecological changes. In the case of changing routine practices, LCA identifies areas of impact on the environment and allows designing the effects of changes in the enterprise.

Numerous manufacturing enterprises that use life cycle assessments refer to such areas as: products, production processes, distribution processes, machinery and equipment, packaging as well as organisation and management. These activities translate into an increase in ecological awareness among consumers, who more and more often make decisions to renounce egoistical self-satisfaction for the implementation of ecological assumptions prevailing in a society (Hoscilowicz, 2008).

The instrument is more and more often introduced to university students who, in the process of teaching knowledge in the field of product ecology, environment, evaluation and design of products, strategies of cleaner production or EMS acquire knowledge of the phases, disadvantages and advantages of LCA. For this purpose, one of the computer programs used in this technique is applied, namely, the SimaPro program, characterised by a reduced number of interactions and their ease of interpretation in relation to other such programs (Umberto, GaBi). The program uses the eco-indicator method, which allows for characterisation of 11 impact categories assigned to three categories of damage, namely, damage to human health, damage to the quality of the ecosystem and damage to the use of natural resources (Lesiuk, Kusmierz \& Oleszczuk, 2012]. Programs of this type can be successfully used in higher education because they often contain standard output data and allow for access to all types of data, which is important in relation to difficulties with obtaining data for the LCI phase (Zarebska, 2013). They allow for an easy and legible analysis of the product and parts used for its assembly. The examples of actions that can be performed in the SimaPro program are presented in Figures 2-6.

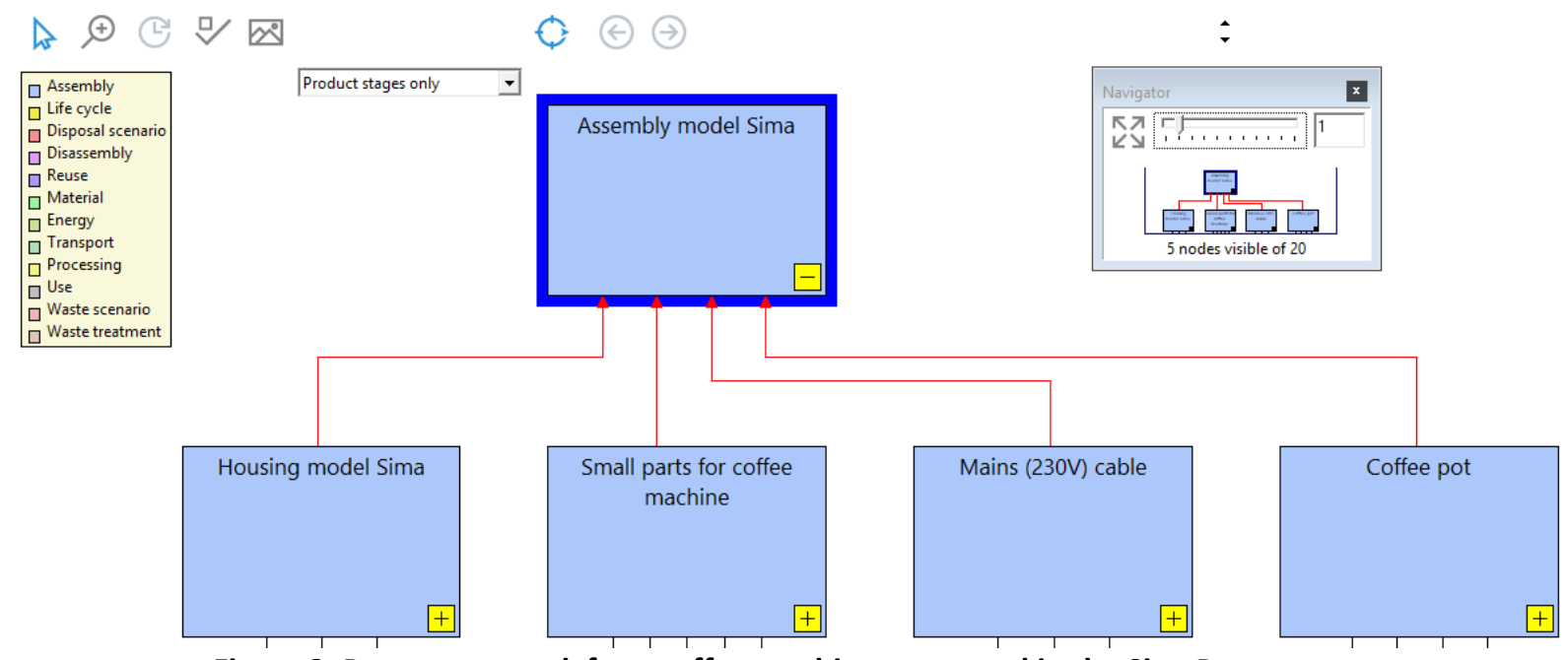

Figure 2. Process network for a coffee machine presented in the SimaPro program

[Source: SimaPro program] 
Figure 2 presents a process network for a coffee machine made of polypropylene, 15 small parts made of metal, plastic and copper. The graphic presentation of the list of materials and processes used to create the product is very clear and understandable. The set of inputs and outputs is shown in Figure 3.

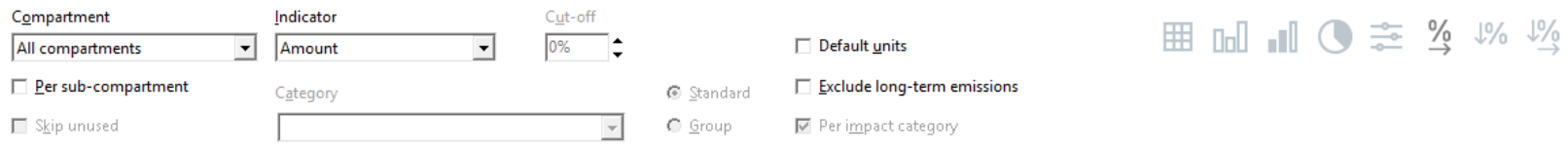

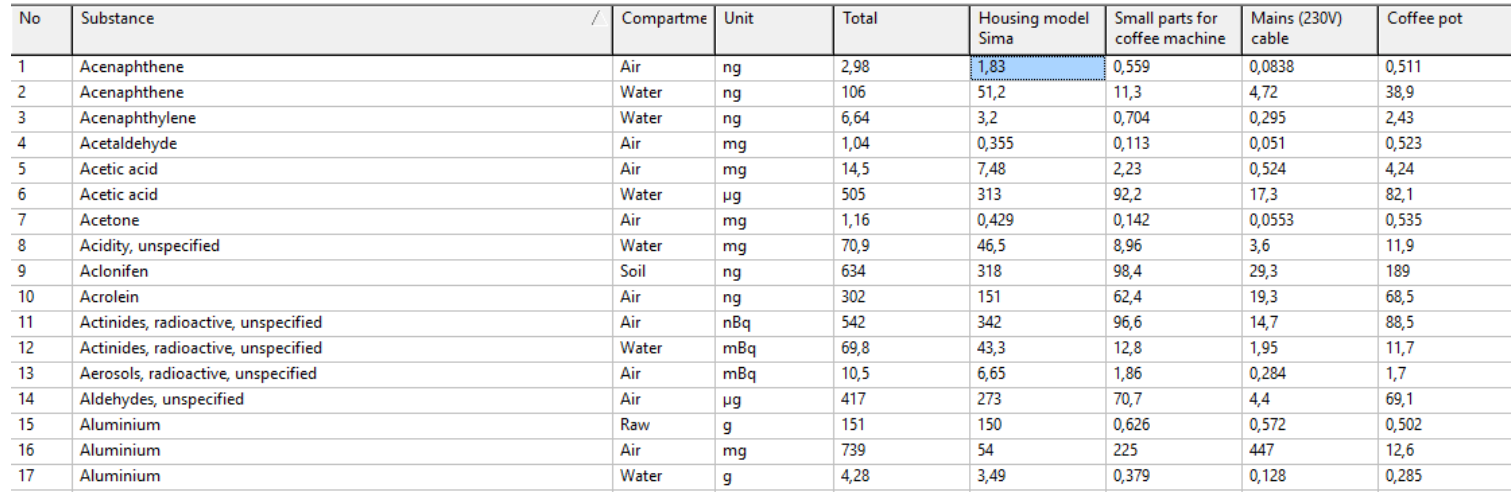

Figure 3. List of materials extracted from the ground and emissions during extraction and production of a coffee machine provided in the SimaPro program

[Source: SimaPro program]

The first column presents the cumulative value of all processes related to the extraction of materials and the production itself. The remaining columns show the contribution of individual components as a list of all substances.

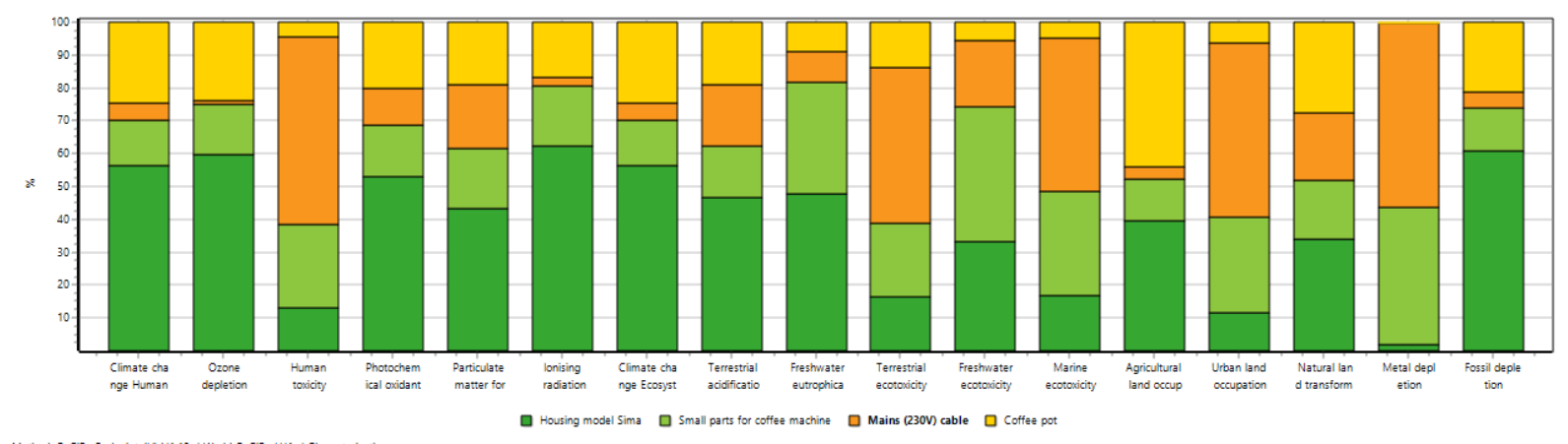

Figure 4. Characterisation results carried out for a coffee machine in the SimaPro program

\section{[Source: SimaPro program]}

Figure 4 presents the results of characterisation, which is a mandatory stage of the LCA analysis, using the ReCiPe Endpoint indicator $(\mathrm{H})$. This step consists in calculating the value of the impact category indicator, and its value informs about the share of a particular chemical in a particular impact category. The results are scaled up to $100 \%$ due to the fact that each category can have a different measure of the unit. To better present the results, a different scale should be used and standardisation should be carried out for this purpose. 


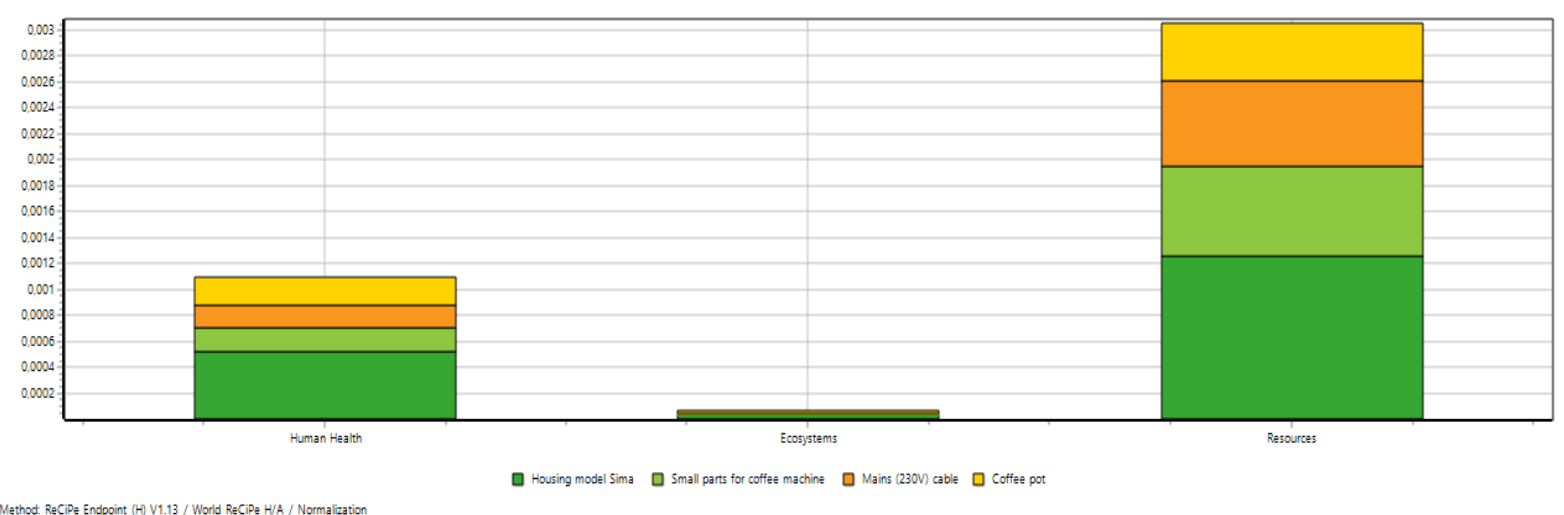

Figure 5. Standardisation results carried out for a coffee machine in the SimaPro program

[Source: SimaPro program

Standardisation, which allows for the conversion of environmental effects per capita in a year, is the first, in accordance with ISO 14042, an optional step of LCA analysis. This presentation of results is not only more readable than characterisation, but standardised results can be compared. It is also possible to specify the impact category indicator for a particular region.

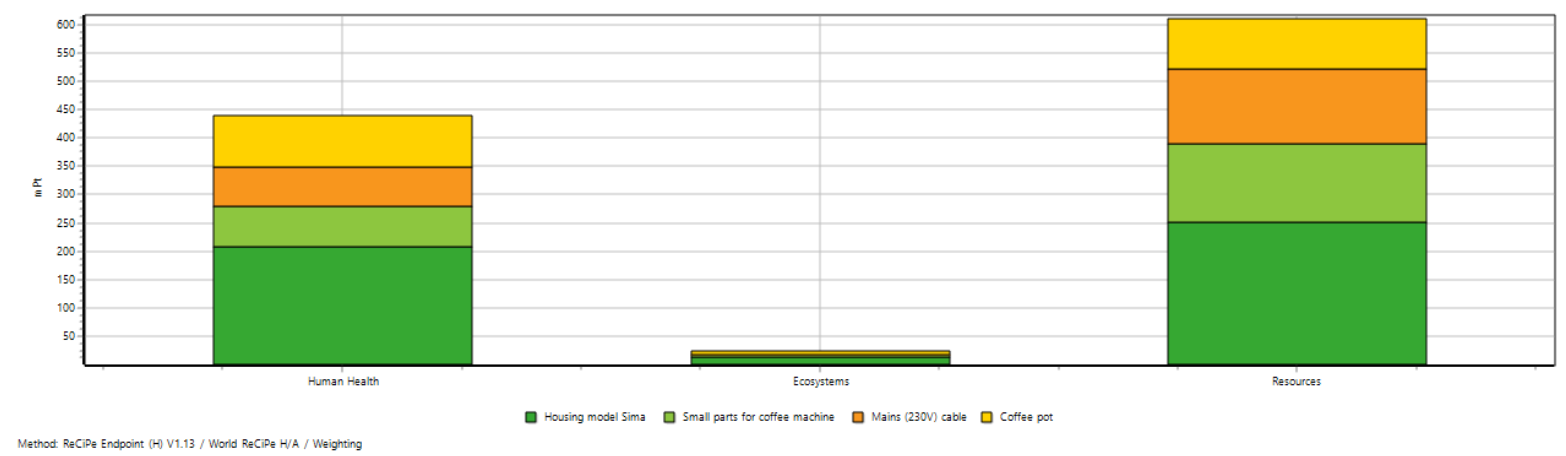

Figure 6. The results of weighing carried out for a coffee machine in the SimaPro program

[Source: SimaPro program]

In accordance with ISO 14042, weighing is also an optional step. At this stage, the standardised results of each impact category are multiplied by a weighting factor that expresses the relative importance of the impact category. The results are presented in the same units so that they can be added to create one result for the product's impact on the environment.

\section{Conclusions}

Environmental awareness of societies, despite the progress of civilisation, is still unsatisfactory. Every human activity has an impact on the surrounding environment, so it is important that this dependence should highlight and make the population aware of the weight of current activities. Shaping ecological awareness is a difficult, long-term and difficult process to verify, but the need to model pro-ecological attitudes is essential for the survival of our planet. Recognising the essence of pro-ecological undertakings by entrepreneurs is important because their actions shape an increasingly conscious population of consumers. The conscious, ecological approach to the product thus sets out activities for other enterprises which, in response to the pro-ecological social pressure, will 
increasingly tend to reflect on the ecological character of their products. Particular attention should also be paid to environmental education, not only at the school level but also at the academic level, where the youth responsible for the future quality of our planet is more aware and responsible. Due to a wide range of possibilities offered by the LCA technique, it can become an extremely helpful tool for ecological education, allowing learners to better understand the relationship between the economic system and the environment. The quality of environmental education will also be positively influenced by the ability to document the environmental impact of the product as well as to design preventive actions and prioritise product improvement. The growing number of universities and research centres using this tool fills with optimism and testifies to the growing role of modern tools in the process of ecological education

\section{References}

Adamczyk, J., Dzikuc, M. \& Zarebska, J. (2015). Implementacja oceny cyklu życia w wyznaczaniu kosztow zewnetrznych funkcjonowania elektrociepłowni konwencjonalnych w Polsce-studium przypadku. Systemy wspomagania w inzynierii produkcji-jakosc i bezpieczenstwo, 3(12), 172-189.

Buchart-Korol, D. (2009). Zastosowanie oceny cyklu zycia (LCA) w analizie procesow przemyslowych. Problemy ekologii, 13(6), 300-305.

Buchart-Korol, D. (2010). Ekoprojektowanie-holistyczne podejscie do projektowania. Problemy ekologii, 14(3), 116-120.

Chrzanowska, M. (2014). Edukacja Ekologiczna jako paradygmat kształcenia i wychowania XXI wieku. Społeczeństwo i Edukacja-Międzynarodowe Studia Humanistyczne, (2), 147-160.

Dabrowska, M. (2008). Ekoinnowacje. Polska Agencja Rozwoju Przedsiębiorczosci, 8-9.

Earles, J. M. \& Halog, A. (2011). Consequential life cycle assessment: a review. The International Journal of Life Cycle Assessment, 16(5), 445-453. doi:10.1007/s11367-011-0275-9

Graczyk, M. \& Kazmierczak-Piwko, L. (2011). Uwarunkowania dla tworzenia wiedzy i innowacji ekologicznych w przedsiębiorstwie. Studia i Materiały Polskiego Towarzystwa Zarzqdzania Wiedzq, 45, 113.

Grzybowska-Brzezinska, M. (2011). Swiadomosc ekologiczna konsumentow a ich zachowania na rynku zywnosci. Studies \& Proceedings of Polish Association for Knowledge Management, 51, 242-243.

Hoscilowicz, E., Janowska, I. \& Meredyk, K. (2008). Instrumenty marketingu jako czynnik ekspansji sektora zywnosciowego (p. 37). Bialystok, Poland: Wyzsza Szkola Finansow i Zarzadzania.

Joachimiak-Lechaman, K. (2014). Srodowiskowa ocena cyklu zycia (LCA) i rachunek kosztow cyklu zycia (LCC). Ekonomia srodowiska, 1(48), 80-96.

Kaminska, E. \& Skarbek-Zabkin, A. (2015). Analizy ekobilansowe w szacowaniu obciazen srodowiska. Transport samochodowy, 1, 49-66.

Klos, L. (2014). Swiadomosc ekologiczna Polakow jako podstawa "Zielonej gospodarki". Ekonomia i srodowisko, 2(49), 298-318.

Kowalski, Z., Kulczycka, J. \& Goralczyk, M. (2007). Ekologiczna ocena cyklu życia (LCA (pp. 10-15). Warsaw, Poland: Wydawnictwo Naukowe PWN.

Kurzydło, M. (2014). Mozliwosc zastosowania techniki LCA do oceny wpływu na srodowisko odpadow przemysłowych i energetycznych. Inzynieria i ochrona srodowiska, 17(4), 597-617.

Lesiuk, A., Kusmierz, M. \& Oleszczuk, P. (2012). Zastosowanie LCA w ekologicznej ocenie produktow, technologii i gospodarce odpadami, Absorbenty i katalizatory-Wybrane technologie a srodowisko. Nauka dla gospodarki, 2, 453-466.

Michalska, M. (2016). Edukacja ekologiczna jako niezbędny element ksztalcenia na studiach wyzszych. Prace naukowe Uniwersytetu Ekonomicznego we Wrocławiu, (453), 235-246.

Niankara, I. \& Zoungrana, D. T. (2018). Interest in the biosphere and students environmental awareness and optimism: a global perspective. Global Ecology and Conservation, 16. doi:10.1016/j.gecco.2018.e00489 
Nitkiewicz, T. (2015). Wykorzystanie ekologicznej oceny cyklu zycia w realizacji przedsiewziec proekologicznych przez przedsiebiorstwa produkcyjne. Prace naukowe Uniwersytetu Ekonomicznego we Wrocławiu, (377), $54-72$.

Pawul, M. \& Sobczyk, W. (2011). Edukacja ekologiczna w zakresie gospodarki odpadami jako narzedzie realizacji zrównoważonego rozwoju. Problems of sustainable development, 6(1), 147-156.

Poskrobko, T. (2007). Proekologiczne kształtowanie produktow (pp. 279-289). Zarzadzanie srodowiskiem. Warsaw, Poland: Polskie Wydawnictwo Ekonomiczne.

Regulation of the Minister of National Education of 30 May 2014 amending the regulation on pre-school education and general education in particular types of schools, Journal of Laws 2014 item 803.

Rosicki, R. (2010). Miedzynarodowe i europejskie koncepcje zrownowazonego rozwoju. Przeglad NaukowoMetodyczny, (4), 44-56.

Terlecka, M. (2014). Dwanaście zasad wspołczesnej edukacji ekologicznej w mysli Alberta Shweitzera. Edukacja ekologiczna-wybrane problem (pp. 163-174). Krosno, Poland: Wydawnictwo AMAGRAF.

Wozniak, M. (2011). Zrownowazony rozwoj jako strategia definiujaca nowoczesne gospodarowanie przestrzenią w Polsce (aspekty prawne). Rocznik Ekonomia i Prawo, VII, 130-144.

Zarebska, J. (2013). Ocena cyklu zycia (LCA) jako innowacyjny instrument edukacji ekologicznej wdrazany na poziomie szkolnictwa wyszego. General and Professional Education, (4), 39-46. 